\title{
SEPARATE REGULATIONS REGARDING THE RECOVERED TERRITORIES IN THE LAW OF PEOPLE'S POLAND
}

\begin{abstract}
The paper contains an analysis of those legal regulations of the People's Poland which were specific to the Recovered Territories and an attempt to answer the question of why such regulations were created. The following sources of law are discussed: legal acts devoted entirely to the Recovered Territories; legal acts applied to the entire territory of Poland in which some provisions were devoted exclusively to regulating the situation in these areas; legal acts that formally applied to the entire territory of Poland, but in the Recovered Territories their regulations were of particular importance. The internal regulations of the Ministry of the Recovered Territories were also examined.
\end{abstract}

Keywords: People's Poland, Recovered Territories of Poland, western and northern territories of Poland, Ministry of the Recovered Territories (Poland), really existing socialism.

\section{ODRĘBNE REGULACJE DOTYCZĄCE ZIEM ODZYSKANYCH W PRAWIE POLSKI LUDOWEJ}

Streszczenie. Artykuł zawiera analizę regulacji prawnych Polski Ludowej odrębnych dla Ziem Odzyskanych oraz próbę odpowiedzi na pytanie, dlaczego takie przepisy były tworzone. Omówiono następujące źródła prawa: akty prawne w całości poświęcone Ziemiom Odzyskanym; akty prawne obowiązujące na terenie całej Polski, w których część przepisów odrębnie regulowała sytuację na tych terenach, a także takie akty prawne, które formalnie dotyczyły całej Polski, ale na Ziemiach Odzyskanych ich znaczenie było szczególne. Przebadano również wewnętrzne przepisy Ministerstwa Ziem Odzyskanych.

Słowa kluczowe: Polska Ludowa, Ziemie Odzyskane, ziemie zachodnie i północne, Ministerstwo Ziem Odzyskanych, realny socjalizm.

\section{INTRODUCTION}

Separate legal provisions for individual parts of the state are usually associated with federal states or some form of autonomy, e.g. regional autonomy, where the creation of local law with the rank of a statute is the purview of local authorities (Izdebski 2014, 58). There were significant changes in the Polish political system

* Jagiellonian University in Krakow, Poland, Faculty of Law and Administration, Department of History of Legal and Political Doctrines, piotr.eckhardt@doctoral.uj.edu.pl 
after World War II, but the country remained a unitary state. Nevertheless, in the first years after the end of the war, legal regulations were created for some parts of the country that were different from those applied in the rest of Poland. This space was the territory of the German Reich and the Free City of Danzig, which, according to the provisions of the Potsdam Conference, was granted to Poland (Konopka and Konopka 2003, 290). At that time, state authorities, for political reasons, promoted the name "Recovered Territories" for these areas. Later, the more neutral term "Western Lands" became popular, which, however, did not include the territory of former East Prussia. After 1989, the terms "newly acquired lands," "former territories taken over by Poland," and, perhaps the most popular, "western and northern territories" appeared in the literature (Tyszkiewicz 2018). In this paper, the terms Recovered Territories and the western and northern territories will be used interchangeably.

Separate legal regulations concerning these areas have not been comprehensively studied yet. Studies in the history of law are devoted to individual legal acts, especially those that remain of practical importance to this day, e.g. in re-privatization proceedings. There are also valuable historical works on various aspects of the management of the Recovered Territories, including those cited in this text, but in these works, the law only provides the backdrop for research on political or social history. Therefore, the subject of this paper is an initial query of the most important legal acts of the People's Poland, ${ }^{1}$ on the basis of which the western and northern territories were regulated differently than in other areas of the country. The analysis covers legal acts entirely devoted to the Recovered Territories; country-wide acts, some fragments of which contain separate regulations for the Recovered Territories; the internal law of administrative bodies managing these areas; and, finally, the law applicable to the entire territory of Poland, which, due to the subject of regulation, was applied mainly or even exclusively in the area of the western and northern territories, including the law from before World War II.

This research, the results of which are presented below, aimed to answer the following question: why were separate legal regulations for the Recovered Territories created in People's Poland? To answer this question, select examples were examined to analyze in what specific situations and how the legal situation of these areas was regulated separately.

${ }^{1}$ People's Poland is the term for the Polish state that existed in the years 1944-1989, used in official propaganda materials, the press and literature. The official name of the People's Republic of Poland is used to describe the Polish state in the years 1952-1989, after the entry of the Polish Constitution of the People's Republic of Poland, passed by the Legislative Sejm on July 22, 1952 (Dz.U. $1952 \mathrm{nr} 33$ poz. 232). 


\section{THE MINISTRY OF THE RECOVERED TERRITORIES}

First, the legal acts that were entirely devoted to the western and northern territories will be discussed. One of the most important acts was the Decree of November 13, 1945 on the Administration of the Recovered Territories (Dz.U. ${ }^{2}$ $1945 \mathrm{nr} 51$ poz. 295), which created a separate public administration structure for these territories only. According to Art. 1, "for a transitional period, as long as extraordinary needs require it," the Ministry of Recovered Territories (MRT) was created. The next article contained a specific definition of the Recovered Territories - the newly created ministry was to cover "the lands recovered west and north to the state borders in 1939." According to Art. 3, the MRT was to prepare a development plan for these areas and ensure its implementation, carrying out a settlement action, management of the post-German property as well as administration of the regained lands. The purview of the Minister of Recovered Territories included all matters that outside this area belonged to the Minister of Public Administration. The role of the MRT was, therefore, twofold. On the one hand, this institution was to carry out tasks specific to the western and northern territories; on the other hand, it was also responsible for the normal, day-to-day administration. Moreover, the MRT also coordinated the activities of other ministries in the Recovered Territories (with the exception of the Ministry of Foreign Affairs and the Ministry of Shipping and Foreign Trade). The MRT was also empowered to apply to the Council of Ministers for a temporary division of the Recovered Territories into voivodships and counties and the appointment of voivodes. The minister himself was entitled to appoint starosts (heads of county administration) in the area under his control. A completely separate administrative structure was therefore established for the areas that are the subject of this study.

The Ministry of the Recovered Territories existed for just over three years. Its liquidation was carried out on the basis of the Act of 11 January 1949 on the Merger of the Management of the Recovered Territories with the General State Administration (Dz.U. $1949 \mathrm{nr} 4$ poz. 22). The authorities of the People's Republic of Poland decided that the "extraordinary needs" under Art. 1 of the Decree on the Administration of the Recovered Territories ceased to exist, and the "transition period" mentioned had ended.

It should be noted that a separate ministry for the Recovered Territories was established not only for pragmatic reasons, such as the specificity of problems occurring in these areas that requiring a different approach and extraordinary tools, e.g. the issues of the post-German estates, the vast number of incoming

${ }^{2}$ Dz.U. is the Polish abbreviation for the Journal of Laws of the Republic of Poland (Dziennik Ustaw Rzeczypospolitej Polskiej), which is not available in English. Therefore, the publication references were left in the Polish version, so that at least those readers who speak Polish could easily find the full texts of the legal acts. 
settlers and the need to create an administration from scratch. There were also political reasons behind the decision to create it. In the first years after World War II, People's Poland did not yet have a one-party political system. At the head of the Ministry of Public Administration and the Ministry of Agriculture and Agricultural Reform stood politicians from the pre-war peasant Polish People's Party. The creation of a new ministry that would take over the management of the Recovered Territories and which would be headed by the communist Władysław Gomułka was, therefore, a priority political goal of the communists (Łach 1995, 136).

Previously, other forms of management of the Recovered Territories were proposed. In April 1945, the Council of Ministers adopted the conclusions of the communist Edward Ochab, the then Minister of Public Administration, appointing him the Plenipotentiary General for the Recovered Territories and establishing the office of the Undersecretary of State for the Recovered Territories in his ministry. The Office of the Western Lands, which dealt with the issues of these areas in the earliest period, was also incorporated into the Ministry of Public Administration. Why did this concept of governing the western and northern territories prove to be only temporary? One of the reasons was certainly the takeover of the Ministry of Public Administration by the Polish People's Party. The communists wanted to limit the influence of the agrarian party in these areas.

Of particular significance was the proposal presented to the President of the National Council of Poland, Bolesław Bierut, by the Warsaw District of the Polish Western Union on March 1, 1945. This patriotic organization was established in the interwar period, the original purpose of which was to act for Polish interests on the Polish-German border; it postulated the creation of the Ministry of the Organization of the Western Territories, which would have departments corresponding to the functions of individual ministries, with the exception of the Ministry of National Defense and the Ministry of Foreign Affairs (Majer 2018, 390-391).

\section{INTERNAL LAW OF THE MINISTRY OF THE RECOVERED TERRITORIES}

Due to the existence of a separate ministry dealing exclusively with matters of the western and northern territories, many lower-level legal acts addressed specifically to this part of the country were created. They can be found in the Official Journal of the Ministry of Recovered Territories. The content of these archival sources deserves separate, extensive research. Below are just a few examples of detailed regulations created by the MRT, showing what issues it dealt with and the kinds of problems this ministry solved.

One of the topics that appeared most frequently in the MRT documents is the problem of securing post-German property. On February 22, 1946, an ordinance 
was issued prohibiting the removal of any movable property from the Recovered Territories (Dz.Urz. MZO³ nr 1 poz. 2). When leaving these areas, one could take clothes, food and other similar items but only in quantities necessary during the trip. The removal of anything else had to be authorized by the Minister of Recovered Territories or another minister in certain cases (e.g. Minister of Forests for wood or Minister of Reconstruction for certain building materials).

According to the Ordinance of March 24, 1946 (Dz.Urz. MZO 1946 nr 3 poz. 25), it was decided to conduct an inventory of post-German movable property, including those located in private apartments and farms already settled by Poles. All movables located in the Recovered Territories were considered post-German property unless their owners came to the area after the war and could document that they brought particular items with them or had previously inhabited these areas but were verified as Polish nationals. The relevant offices verified the census forms filled in by the owners of post-German property and determined which items were necessary, taking into account their profession and the size of their families. The remaining movable property, considered surplus, was to be taken from the owners and transferred to other settlers or sold to the existing owner at an estimated price.

By the Ordinance of May 12, 1946, special bonuses were established for persons who contributed to the disclosure of hidden post-German property in order to stop the illegal removal of such property from the Recovered Territories (Dz.Urz. MZO $1946 \mathrm{nr} 4$ poz. 28). Detailed instructions on the method of securing post-German property were also contained in numerous circulars from the MRT. For example, Circular No. 28 (Dz.Urz. MZO $1946 \mathrm{nr} 4$ poz. 38) critically refers to the practice of arbitrary management of post-German property by mayors and presidents of cities without reporting these items to the relevant offices. However, care was taken not only about material values. Circular No. 33 (Dz.Urz. MZO $1946 \mathrm{nr} 4$ poz. 41) ordered the keeping of city chronicles as well as securing and collecting materials regarding the historical past of the western and northern territories.

\section{POLISH CITIZENSHIP OF THE RESIDENTS OF THE RECOVERED TERRITORIES}

Not all of the previous inhabitants left the western and northern territories at the end of the war. Some of them wanted and were able to stay there, regardless of their German citizenship, if they were of Polish nationality. The

${ }^{3}$ Dz.Urz. MZO is the Polish abbreviation for the Official Journal of the Ministry of Recovered Territories. The publication references were left in Polish for the same reasons as in the case of the Journal of Laws of the Republic of Poland. 
status of this group is another area of activity of the MRT and the area of legal regulations issued by this institution. The ordinance of April 6, 1946 (Dz.Urz. MZO $1946 \mathrm{nr} 4$ poz. 26) regulated the procedure for confirming the Polish nationality of people who lived in the Recovered Territories. In order to be recognized as a Polish national, one had to prove their Polish origin (e.g. a surname that sounds Polish) or show their relationship with the Polish Nation (e.g. by fighting for Polish independence, belonging to Polish organizations, or cultivating Polish traditions). However, members of certain German organizations, teachers of German schools and people whose behavior showed full ties with the German nation, even if they were of Polish origin, were not considered a part of the Polish Nation. It is easy to notice that the criteria for recognizing people without Polish origin as belonging to Polish nationality and not recognizing them as such despite having Polish origin were formulated in a very general and discretionary manner.

Official confirmation of Polish nationality was needed to obtain (after submitting a declaration of fidelity to the Polish Nation and the Polish State) Polish citizenship on the basis of the Act of April 28, 1946 on the Citizenship of the Polish State of Persons of Polish Nationality Residing in the Recovered Territories (Dz.U. $1946 \mathrm{nr} 15$ poz. 106) - another piece of legislation adopted specifically for the western and northern territories, but so laconic that it does not need to be discussed separately. The regulations of this act were limited to stating that the right to Polish citizenship is granted to persons who obtained confirmation of belonging to Polish nationality. That is why the Ordinance of the MRT of April 6, 1946, analyzed above, established detailed rules on how citizenship would be granted in practice. Moreover, the property of the person who obtained confirmation of the Polish nationality on the basis of this ordinance was not treated as post-German property.

\section{POLONIZATION OF GERMAN NAMES AND SURNAMES}

Citizenship was not the only attribute of the population that remained in the Recovered Territories, which the authorities of the People's Poland wanted to sort out according to their political objectives. Much attention was paid to the issue of German names and surnames and Polish surnames with German spelling. This is a case in which the acts of the internal law of the Ministry of the Recovered Territories played a special role. The formal basis for their change was the Decree of November 10, 1945 on Changing and Determination of Names and Surnames (Dz.U. $1945 \mathrm{nr} 56$ poz. 310) - a regulation that applied to the entire country. According to its provisions, a surname change was only possible for important reasons, in particular, if the name was disgraceful or ridiculous; if someone took a different surname as a military pseudonym during the fight for 
Poland during World War II; if he or she assumed a different surname in order to hide their identity during the German invasion or if they had a non-Polish surname (Art. 3). The name change was possible for similar reasons (Art. 10). Most importantly, in accordance with Art. 1, the change of the name or surname was the subjective right of a Polish citizen. It was to be made only at his or her request. Therefore, it was up to him or her whether he or she will make use of this option or not.

The archival research of the historian Anna Jankowska-Nagórka shows, however, that the practice was different in the western and northern territories. Between 1945-1949, i.e., during the existence of the Ministry of the Recovered Territories, an extensive campaign of Polonization of German or Germansounding indigenous surnames was carried out (Jankowska-Nagórka 2018, 219 220). Historical documents indicate that significant pressure was exerted on the population during this operation, and changes were often made under duress (Jankowska-Nagórka 2018, 225). On what basis were such actions taken if the Decree on the Change and Determination of Names and Surnames established the possibility of changing these personal data as a citizen's subjective right?

The operation was based on Circular No. 22/48 of the MRT on the changing of names and surnames, preserved in the archives but not published even in the Official Journal of the MRT. It contained many solutions to exert pressure on the population and carry out the Polonization campaign as soon as possible and on the largest possible scale. For example, once submitted, a declaration of a name change could not be withdrawn. The officials were supposed to "convince" people who were used to their German surnames but "not showing any ill will" and "make them aware." On the other hand, those showing ill will were to be reported to the county administration. For those reluctant to change their name, sanctions were introduced - a reprimand, changing the apartment for the worse, dismissal from office or a fine of up to 30,000 zlotys (JankowskaNagórka 2018, 222).

The operation of changing German surnames in the area of the Recovered Territories is an example of a situation in which separate regulations for the area of the western and northern territories were applied at the level of the internal law of the ministry, which were not only issued without an explicit basis in any decree or statute but, moreover, clearly contradictory with the Decree on the Change and Determination of Names and Surnames binding throughout the country. This decree regulated the change of (also non-Polish) surnames as a citizen's right. Circular No. 22/48 of the MRT treated the Polonization of a German-surname as the duty of a Polish citizen, the avoidance of which could be punished. Perhaps this circular was not published in the Official Journal of the MRT because of the illegality of MRT's actions, even in the context of the legislation of People's Poland. 


\section{POLONIZATION OF GEOGRAPHICAL NAMES}

Another major task of public administration in the Recovered Territories was related to the change of German geographical names to Polish language ones. Such a change was urgent because very few German names had a longer history - many were the direct fruit of Nazi policy. Many geographical names in the western and northern territories for centuries had Slavic roots. However, during the Third Reich, especially between 1937-1938, a mass change of geographical names to Germanic was carried out in order to erase all traces of Slavicness in these areas (Utracki 2013, 50).

It is therefore not surprising that the Minister of Recovered Territories, together with the Minister of Public Administration, issued numerous ordinances on the restoration and establishment of official names of places, e.g. on May 7 (M.P. $1946 \mathrm{nr} 44$ poz. 85), November 12, 1946 (M.P. $1946 \mathrm{nr} 142$ poz. 262) and March 15, 1947 (M.P. 1947 nr 37 poz. 297). Such ordinances essentially consisted of tables containing the Polish name, an adjective derived from that name and the former German name.

Why was the Official Gazette of the Republic of Poland, and not the Official Journal of the Ministry of Recovered Territories, the original place of publication of these ordinances? The reason was the legal basis on which the changes to the geographical names were made. It was an act formally binding in the country, one that dated back to before World War II - the Ordinance of the President of the Republic of October 24, 1934 on Establishing Place Names and Property Numbering (Dz.U. 1934 nr 94 poz. 850). Pursuant to this ordinance, the changes of geographical names were made by the Minister of the Interior (after World War II in the Recovered Territories by the Minister of Recovered Territories) through the ordinances published in the Official Gazette of the Republic of Poland (Art. 2). These decisions were to be made on the basis of the recommendations of the Commission for Establishing the Names of Places established pursuant to Art. 3 of the analyzed act, consisting of representatives of state authorities and scientists.

Despite the fact that it formally applied to the entire territory of Poland, the discussed regulation was almost exclusively applied in the Recovered Territories (and in part of Silesia, which was not part of the Recovered Territories but was heavily Germanized during the Nazi occupation). Changes in names in other parts of the country were sparse. They were limited to a few individual ordinances - for example, the Ordinance of the Minister of Public Administration of August 8, 1946 regarding the change of the name of one

${ }^{4}$ M.P. is the Polish abbreviation for the Official Gazette of the Republic of Poland (Monitor Polski). The publication references were left in Polish for the same reasons as in the case of the Journal of Laws of the Republic of Poland. 
town in the Kielce Province (M.P. 1946 nr 83 poz. 154) or the Ordinance of the Minister of Public Administration of January 31, 1947, on the change of the name of one housing estate (M.P. $1947 \mathrm{nr} 76$ poz. 494). The full concentration in the western and northern territories is also confirmed by the organization of the work of the Commission for Establishing Names of Places, which was reactivated after the war. Within this framework, three regional commissions were established. All of them dealt with individual parts of the Recovered Territories (and the aforementioned fragment of Polish but Germanized Silesia) - the first in Silesia, the second in Eastern Pomerania and the third in Western Pomerania and the Lubusz Land (Utracki 2011, 115). Moreover, in practice, the scope of the commission's work was determined by the content of the German topographic map sheets at a scale of 1:100,000 issued after 1933. The commission aimed to replace all German names on this map with Polish names (Gołaski 2008, 46).

The Ordinance of the President of the Republic of Poland of October 24, 1934 on Establishing the Names of Places and Property Numbering was, therefore, a notable example of a legal act created for the entire territory of Poland. It turned out to be particularly useful after 1945 , for solving problems related to the situation of the western and northern territories, constituting the legal basis for the activities of the Minister of Recovered Territories.

This preliminary and cursory review of the internal legal acts of the MRT shows that the main areas of the ministry's activities were related to solving problems specific to the western and northern territories, as areas previously belonging to another state - the issues of the acquired property, the local population that remained and a large number of settlers coming to these areas. On the other hand, the Ministry of Public Administration fully replaced the MRT in the western and northern territories, not only in matters specific to these areas. Therefore, circulars on problems that occurred throughout post-war Poland, such as fisheries, allotment gardens and the reconstruction of slaughterhouses, can be found in the Official Journals of the MRT.

At the end of this preliminary analysis of internal legal acts distinct to the western and northern territories, it should be noted that there were also several ordinances issued by other ministers that explicitly concerned these areas, e.g. the Ordinance of the Minister of Supplies and Trade of October 6, 1945 on Disposing of Post-German Goods (Dz.Urz. MZO $1946 \mathrm{nr} 1$ poz. 22) or the Ordinance of the Ministers of Industry and Treasury of August 25, 1945 on Bank Loans for Starting Industry in the Recovered Territories (Dz.Urz. MZO $1946 \mathrm{nr} 1$ poz. 20). Their common feature is the date of issue before the formation of the MRT. 


\section{CITIZENS' GUARD IN THE RECOVERED TERRITORIES}

Another notable legal act establishing institutions specific to the western and northern territories was the Decree of March 1, 1946 on the Citizens' Guard in the Recovered Territories (Dz.U. $1946 \mathrm{nr} 10$ poz. 71). The decree established the Citizens' Guard in rural communes and the so-called non-designated cities (Art. 1). Its tasks included cooperation with the authorities of the Citizens' Militia to ensure security, maintain public order and protect public property, as well as assistance and defense in the event of a threat to the personal safety of fellow citizens or their property (Art. 2). Service in the Citizens' Guard was compulsory and unpaid (Art. 5), with a working time not to exceed sixteen hours a week (Art. 8). While performing their duties, members of this formation had the right to carry firearms (Art. 9) and use them in certain cases (Art. 11 and 12). They also had the right to ID and detain suspects (Art. 10).

Notably, at the same time, another organization supporting the Citizens' Militia was established. The Resolution of the Council of Ministers of February 21, 1946 established the Voluntary Citizens' Militia Reserves $\left(\mathrm{ORMO}^{5}\right)$, the tasks of which were formulated similarly to those of the Citizens' Guard. They were to support the Citizens' Militia in combating banditry, robbery and other crimes, assist its organs and prepare reserves to supplement its ranks (Pączek 2012, 90). However, unlike the Citizens' Guard, service in the ORMO was voluntary (Pączek $2012,89)$. The structures of this organization were to be created throughout the country and thus also in the Recovered Territories.

The historian Tomasz Pączek has noted that the motivations behind the creation of the Citizens' Guard are not entirely clear. He raises the question of why the communist authorities decided to take this step if the main organization supporting the security apparatus was to be the ORMO (Pączek 2012, 88). A partial answer can be found in studies on the history of the individual parts of the western and northern territories in the earliest period after World War II. For example, in connection with the problems of maintaining security and order in the Recovered Territories, particularly the large number of thefts and robberies, the Poznan Voivode recommended that the district administrations create civic guard units as early as October 1945 (Rymar 1997, 160). In 1945, the civic guard was also created on the Polish-German border, settled by demilitarized soldiers as part of the so-called military settlement. That formation was to consist of military settlers equipped with weapons (Osękowski 1993, 58).

On the other hand, in Głogów, after the analyzed decree was issued, previously formed self-defense groups were reorganized according to its

${ }^{5}$ ORMO is the Polish abbreviation for Voluntary Citizens' Militia Reserves (Ochotnicze Rezerwy Milicji Obywatelskiej). This abbreviation was widely used and much better known than the full name of this formation. 
regulations (Chutkowski 1997, 27). Therefore, it can be surmised that the purpose of issuing the Decree on the Citizens' Guard in the Recovered Territories was not to create new formations but to provide a legal framework for groups that already existed. On the other hand, similar civic guards were also created in other parts of post-war Poland, e.g. in Gostynin (Maciejewski 1980, 7), and their activities were not formalized.

However, in the western and northern territories, the recruitment of volunteers to the ORMO was problematic. For example, in Western Pomerania, the number of members of this organization increased significantly only before the referendum on, inter alia, the agricultural reform planned for June 1946, because then the activists of the Polish Workers' Party began to join it (Kersten 1965, 18). Formalization of the previously existing civic guards in the Recovered Territories - and only there - could have been the result of both greater crime, and the slow organization of ORMO in these areas.

Formally, the Decree on the Citizens' Guard in the Recovered Territories was repealed pursuant to Art. 24 of the Act of June 13, 1967 on the Volunteer Reserve of Citizens' Militia (Dz.U. 1967 nr 23 poz. 108). However, based on the available historical sources, it can be argued that the Citizens' Guard units ceased their activities much earlier. For example, in Gorzów Wielkopolski, the Citizens' Guard appears to have been liquidated at the end of 1946 (Rymar 1997, 161). Therefore, it was another legal institution of a temporary nature, the purpose of which was to solve the problems specific to the Recovered Territories (in this case related to the security), and not to shape a permanent separate legal or factual situation in these areas. It is worth mentioning that, unlike the Citizens' Guard, the ORMO survived until the political transformation.

\section{NATIONAL TRIBUTE FOR THE DEVELOPMENT OF THE RECOVERED TERRITORIES}

A legal act entirely devoted to the issues of western and northern territories can also be found in tax law. These areas are covered by the Decree of November 13, 1946 on the National Tribute for the Development of the Recovered Territories (Dz.U. $1946 \mathrm{nr} 10$ poz. 71). Art.1 introduced a "national tribute," which was defined as a universal, one-time levy for "accelerating the development of the Recovered Territories and their economic unification with the Motherland." According to Art. 2 of the decree, the receipts from the "national tribute" could only be used for this purpose. As stated in Art. 3, the obligation to pay this levy was, inter alia, on taxpayers of the real estate tax (equal to the amount of the tax for 1946); turnover tax (also depending on the amount of this tax); land tax, i.e., tax on the agricultural real estate (depending on the size of the farm, the rate being progressive) and tax on wages (depending on the amount of remuneration 
- in this case, the rate was also progressive, from 0.5 to $15 \%$ ). It was possible to be obligated to pay the national tribute for several titles simultaneously (e.g. as a real estate owner receiving remuneration for work). In order to collect this levy, civic commissions of various levels were appointed, from commune and district committees to the main commission operating at the national level.

Contrary to most of the discussed regulations, the Decree on the National Tribute for the Development of the Recovered Territories did not refer to these areas by designating a group of addressees because the obligation to pay the levy was imposed on the inhabitants of all of Poland. The legal instrument was introduced in order to accelerate the development of the western and northern territories.

According to official propaganda, the funds collected as part of this tribute were to express the Polish nation's gratitude toward the Recovered Territories for their contributions to the national economy. It was also referred to as "a response to revisionist German attempts" (Osadnik na Ziemiach Odzyskanych 1946, 1). The Prime Minister of the Provisional Government of National Unity called the national tribute to develop the Recovered Territories "a measure of the effort and the resolute will of the nation to maintain the Western Lands" (Echo Poludnia 1946, 1). Bolesław Bierut wanted "the national tribute to transform the Recovered Territories into a [Polish] defensive bastion in the west" (Jedność Narodowa 1946, 1). As can be seen, the national tribute for developing the Recovered Territories was of great political importance to the communist authorities. However, on the basis of the available sources, it is difficult to determine its actual significance for the economy and the post-war reconstruction of the western and northern territories. It is impossible to establish what exactly these funds were spent on (Pazgan 2014, 86).

As a one-off levy, the national tribute for the development of the Recovered Territories was another legal instrument of a temporary nature, the purpose of which was to eliminate the differences between the western and northern territories and the rest of Poland, rather than consolidate and deepen them.

\section{DECREE ON THE ABANDONED AND POST-GERMAN GERMAN ESTATES}

The Ordinance of the President of the Republic of Poland of October 24, 1934 on Establishing Place Names and Property Numbering was not the only legal act that was more significant for the western and northern territories than for the rest of post-war Poland. Art. 2 sec. 1 of the Decree of March 8, 1946 on Abandoned and Post-German Estates (Dz.U. $1946 \mathrm{nr} 13$ poz. 87) stipulated that all property of the German Reich and the former Free City of Danzig, of citizens of the German Reich and the former Free City of Danzig, with the exception of persons of Polish nationality or any other nationality persecuted by the Germans, and of German 
and Danzig's legal persons and companies controlled by German and Danzig's citizens became the property of the state by law. Therefore, the scope of these provisions was defined personally. Nevertheless, it was obvious that they were mainly used in the Recovered Territories where most of the property belonging to German or Danzig citizens, companies and legal persons was located.

In other parts of Poland, such situations were rare; although, of course, in these few cases, the provisions in question also applied. However, Art. 1 of the discussed decree primarily applied to assets located in other parts of the country, which concerned properties abandoned by owners due to warfare. The property was put under state management, but it was transferred to the state only when the owner could not be found and did not make efforts to restore possession within 10 years for real estate and 5 years for movable property (Art. 34). In the case of abandoned estates, the purpose of the legislator's decree was not to nationalize them but to protect the interests of lawful owners (Zawada 2010, 1227).

The Main Liquidation Office and District Liquidation Offices (Section II of the analyzed decree) were established to carry out tasks related to the taking over, securing and handing over to the competent authorities of both abandoned and postGerman properties. It is worth pointing out that, in general, the Liquidation Offices were subordinate to the Prime Minister, but those operating in the western and northern territories were subordinated to the Minister of the Recovered Territories.

The Decree on Abandoned and Post-German Estates is, therefore, a legal act in which the application of the provisions was formally dependent on the personal characteristics of specific entities. However, these features were indicated in such a way that, in practice, the regulations were applied mainly in a specific space - that is, the Recovered Territories.

\section{THE LAND REFORM IN THE RECOVERED TERRITORIES}

Another issue that needs to be discussed is the legal regulation of land reform. It was one of the main points of the political program of the authorities of People's Poland. It is even sometimes called its founding myth (Kowalski 2014). Its conduct was already announced in the declaration of the Central Committee of the Polish Workers' Party of March 1, 1943. This plan was confirmed in the Manifesto of the Polish Committee of National Liberation (PKWN) of July 22, 1944 - the first official document of the emerging authorities of post-war Poland, the content of which was approved by the Soviet authorities (Jastrzębski 2018, 121-122). The legal implementation of this postulate was the Decree of the PKWN of September 6, 1944 on the Implementation of the Land Reform (Dz.U. $1944 \mathrm{nr} 4$ poz. 17). According to Art. 2, for the purposes of reform, agricultural real estates owned by natural persons were allocated if their size exceeded 100 ha of the total area of 50 ha of agricultural land. However, another point of this article stated that 
the land estate of citizens of the German Reich and Polish citizens of German nationality would be designated for the purposes of the land reform regardless of their size. Thus, similar to the above-mentioned Decree on Abandoned and PostGerman Estates, the scope of application of the provisions was formally defined by indicating the personal characteristics of specific entities. However, in most cases, the differences in its application essentially coincided with the borders of the western and northern territories.

Pursuant to the Decree on the Administration of the Recovered Territories, the validity of the Decree of the PKWN on the Land Reform was formally extended to the western and northern territories on November 13, 1945 (Michałowski 2012, 358). However, less than a year later, a separate legal act devoted to the agricultural reform for these areas was issued - the Decree of September 6, 1946 on the Agricultural System and Settlement in the Recovered Territories and the Former Free City of Danzig (Dz.U. 1946 nr 49 poz. 279). Art. 1 stipulated that all agricultural land and estates related to agriculture were to be taken over. However, it is worth pointing out that a large portion was already state-owned on the basis of earlier decrees. Therefore, in practice, these regulations extended the nationalization to only certain categories of real estate, e.g. real estate owned by the German local government (Michałowski 2012, 358). Separate regulations for the Recovered Territories contained certain procedural and formal differences regarding the implementation of the land reform in these areas that corresponded to specific local needs. For example, the institution of the land reserve was regulated in detail (section I of the decree) probably because, unlike other areas of Poland, there was more free land in the western and northern territories than settlers willing to take it, at least initially.

A significant change was introduced by Art. 9 of the discussed decree. The area of farms granted under the agricultural reform in the western and northern territories was increased from 5 to $7-15$ ha and as much as 20 ha in the case of livestock farms. This provision adjusted the land reform principles to the specific nature of those areas where there was more free land to be settled. The possibility of obtaining a larger farm served as an incentive for the settlers.

Art. 18 of the analyzed decree gave priority to obtaining a farm for demobilized soldiers who fought for Poland during the war, including war invalids; widows and orphans of those who died in this fight; repatriates, i.e., people who came, among others from the territories of the Second Polish Republic that remained outside the new Polish borders after World War II, as well as owners of small farms in other parts of Poland. The possibility of receiving a farm was therefore not only a form of compensation for fighting during the war and the losses incurred in connection with that fight, but also an incentive for people who lost their farms due to the shifting of Poland's borders to move to these areas and for those who had farms too small to make a living off of them. The Decree on the Agricultural System and Settlement in the Area of the Recovered Territories 
and the Former Free City of Danzig implemented the same political idea that stood behind the Decree of the Polish Committee of National Liberation on the Implementation of the Agricultural Reform, taking into account the separate specificity of the western and northern territories.

\section{CONCLUSIONS}

The above examples of separate regulations for the Recovered Territories do not exhaustively describe the entirety of such legislation. For the history of law, this work only constitutes preliminary research. However, the analysis of the cases discussed above already allows some general conclusions to be drawn.

Separate legal regulations concerning the Recovered Territories were introduced into the People's Poland's legal system in various ways. These were separate decrees, separate regulations in decrees concerning the entire country, and numerous acts of internal law, the role of which sometimes turned out to be much more significant than their place in the hierarchy of sources of law would indicate.

However, a common feature of the vast majority of provisions that differentiated the legal situation of the Recovered Territories and the rest of the territory of People's Poland can be indicated - their temporal limitations. Some already contain declarations that established solutions for a transitional period (e.g. the Decree on the Administration of the Recovered Territories). Others, such as the Decree on the National Tribute for the Development of the Recovered Territories, granted the authorities a competence to be used only once. Another group of legal acts, for example, those related to the settlement and establishment of farms, regulated certain processes that were assumed to be carried out and completed, creating a permanent, stable situation.

The separate legal regulations for the Recovered Territories from the first years of the history of People's Poland did not result from the fact that the authorities wanted to differentiate the social or economic situation in these areas and the rest of the country. On the contrary, it was the already existing significant differences that influenced the law-making process. The provisions that were introduced on an ad hoc basis responded to problems unique to the western and northern territories, leading, in the long run, to a situation where they would no longer be needed - because the law could be uniform for the whole People's Poland. This was the goal of its authorities, whose intention was not to create any regional distinctiveness. 


\section{BIBLIOGRAPHY}

Chutkowski, Janusz. 1997. Powstanie władzy polskiej w Głogowie i jej działalność w latach 1945-1950 [Establishment of the Polish Government in Gtogów and Its Activities in the Years 1945-1950]. Głogów: Towarzystwo Ziemi Głogowskiej.

Echo Poludnia. 1946. "Premier Osóbka Morawski o Daninie Narodowej” ["Prime Minister Osóbka Morawski on the National Tribute"]. 275: 1.

Gołaski, Janusz. 2008. "Ustalanie i wdrażanie nazw obiektów fizjograficznych na Ziemiach Zachodnich i Północnych Rzeczpospolitej Polskiej" ["Establishment and Implementation of Names of Physiographic Objects in the Western and Northern Territories of the Republic of Poland"]. Polski Przegląd Kartograficzny 40(1): 46-53.

Izdebski, Hubert. 2014. Samorzad terytorialny. Podstawy ustroju i działalności [Local Government. Basics of the System and Activity]. Warszawa: LexisNexis.

Jankowska-Nagórka, Anna. 2018. "Zmiana imion i nazwisk autochtonów na Dolnym Śląsku jako wyraz antyniemieckiej polityki państwa w latach 1945-1949. Kilka refleksji o sposobach postępowania władz" ["Changing the Names and Surnames of Indigenous Inhabitants of Lower Silesia as an Anti-German State Policy of Poland from 1945 to 1949. Some Remarks on Government Actions"]. Res Historica 46: 219-223.

Jastrzębski, Robert. 2018. "Reforma rolna po drugiej wojnie światowej. Ustawodawstwo państwa polskiego" ["Land Reform After World War II. Legislation in Poland"]. Czasopismo Prawno-Historyczne 52(1): 111-151.

Jedność Narodowa. 1946. "Przemówienie Prezydenta K.R.N. ob. Bolesława Bieruta" ["Speech of the Citizen Bolesław Bierut, President of the State National Council"]. 231: 1.

Kersten, Krystyna. 1965. "Początki stabilizacji życia społecznego w środowisku wiejskim na Pomorzu Zachodnim (1945-1947)" ["The Beginnings of Stabilization of Social Life in the Rural Environment in Western Pomerania (1945-1947)"]. Polska Ludowa 4: 3-42.

Konopka, Hanna and Adrian Konopka. 2003. Leksykon historii Polski po II wojnie światowej 19441997 [Lexicon of Polish History After the Second World War 1944-1997]. Warszawa: GrafPunkt.

Kowalski, Waldemar. 2014. "Reforma rolna - mit założycielski Polski Ludowej” ["Agricultural Reform - the Founding Myth of People's Poland"]. Accessed December 1, 2020. https:// muzhp.pl/pl/c/1380/reforma-rolna-mit-zalozycielski-polski-ludowej.

Łach, Stanisław. 1995. "Organizacja osadnictwa miejskiego na Ziemiach Odzyskanych po II wojnie światowej" ["Organization of Urban Settlement in the Recovered Territories After World War II”]. Stupskie Studia Historyczne 4: 125-154.

Maciejewski, Janusz. 1980. "Kształtowanie się władzy ludowej w powiecie gostynińskim" ["The Formation of the People's Rule in the Gostynin County"]. Notatki Ptockie. Kwartalnik Towarzystwa Naukowego Plockiego 25(1): 5-12.

Majer, Tomasz T. 2018. "Kształtowanie się modelu zarządu Ziem Odzyskanych w latach 1944-1945" ["Formation of Polish Administration in the Recovered Territories"]. Studia Prawnoustrojowe 42: 389-402.

Michałowski, Rafał. 2012. "Regulacja obrotu państwowymi gruntami rolnymi w świetle przepisów o reformie rolnej i osadnictwie na Ziemiach Odzyskanych" ["Legal Regulation of Land Property Turnover in the Light of the Decrees on Land Reform and Settlement on Regained Territories"]. Miscellanea Historico-Iuridica 11: 351-372.

Osadnik na Ziemiach Odzyskanych. Dwutygodnik poświęcony sprawom osadnictwa. 1946. "Danina narodowa - życiodajny zastrzyk dla Ziem Odzyskanych" ["National Tribute - Vital Boost for the Recovered Territories"]. 8: 1. 
Osękowski, Czesław. 1993. "Oficjalne i faktyczne cele osadnictwa wojskowego na pograniczu polsko-niemieckim po drugiej wojnie światowej" ["Official and Actual Goals of Military Settlement in the Polish-German Borderland After the Second World War"]. Stupskie Studia Historyczne 3: 53-66.

Pazgan, Mateusz. 2014. “Zagadnienia aprowizacji ludności województwa wrocławskiego z perspektywy starostwa kamiennogórskiego w latach 1945-1947" ["Issues Concerning Victualling of Wrocław Region's Population from the Perspective of the County in the Years 1945-1947’]. Annales Universitatis Mariae Curie-Sktodowska, sectio F-Historia 69: 75-88.

Pączek, Tomasz. 2012. "Ochotnicza Rezerwa Milicji Obywatelskiej w latach 1946-1989. Rozwój organizacyjny i rola w aparacie represji PRL" ["Volunteer Reserve of Citizens' Militia in 1946-1989. Organizational Development and Role in the Repression Apparatus of the Polish People's Republic"]. Aparat Represji w Polsce Ludowej 1944-1989 1: 85-130.

Rymar, Dariusz. 1997. "Powstanie, organizacja i działalność organów bezpieczeństwa i innych służb porządkowych na terenie miasta i powiatu Gorzów Wielkopolski w latach 19451950" ["Establishment, Organization and Operation of Security Authorities and Other Law Enforcement Services in the City and County of Gorzów Wielkopolski in the Years 19451950"]. Nadwarciański Rocznik Historyczno-Archiwalny 4: 123-166.

Tyszkiewicz, Jakub. 2018. "Nazewnictwo terenów przyłączonych do Polski w 1945 r. - zarys problemu" ["Nomenclature of Areas Attached to Poland in 1945 - Outline of the Problem"]. Accessed December 1, 2020. http://szzip.pl/pl/ziemie-odzyskane-ziemie-zachodnie-ipolnocne/

Utracki, Damian. 2012. "Problematyka nazewnicza na Ziemiach Zachodnich. Proces repolonizacji i polonizacji nazw po II wojnie światowej" ["Nomenclature in the Western Territories. The Process of Re-Polonization and Polonization of Names After World War II"]. In Letnia Szkoła Historii Najnowszej 2011: Referaty [2011 Summer School of Recent History: Papers]. 109118. Edited by Przemysław Gasztold-Seń and Łukasz Kamiński. Warszawa: IPN.

Utracki, Damian. 2013. "Polityka onomastyczna władz jako element przywracania polskości na ziemiach zachodnich po II wojnie światowej (na przykładzie nazewnictwa powiatu słubickiego)" ["The Onomastic Policy of the Government as the Element of Restoring the Polish Identity in the Western Recovered Lands After World War II (Using the Example of the Nomenclature in the Słubice County)"]. Studia Zachodnie 15: 49-65.

Zawada, Kazimierz. 2010. "Powojenne ustawodawstwo o majątkach opuszczonych. Założenia i funkcjonowanie-próba oceny" ["An Attempt at Evaluation of the Foundations and Functioning of the Postwar Legislation on Abandoned Property"]. In Vetera novis augere: studia i prace dedykowane Profesorowi Wacławowi Uruszczakowi [Vetera novis augere: Studies and Works Dedicated to Professor Wactaw Uruszczak]. 1225-1238. Edited by Stanisław Grodziski, Dorota Malec, Anna Karabowicz and Marek Stus. Kraków: Wydawnictwo Uniwersytetu Jagiellońskiego.

\section{Legislation}

Rozporządzenie Prezydenta Rzeczypospolitej z dnia 24 października 1934 r. o ustaleniu nazw miejscowości i o numeracji nieruchomości [Ordinance of the President of the Republic of Poland of October 24, 1934 on Establishing Names of Places and on Property Numbering] (Dz.U. 1934 nr 94 poz. 850).

Dekret Polskiego Komitetu Wyzwolenia Narodowego z dnia 6 września 1944 r. o przeprowadzeniu reformy rolnej [Decree of the Polish Committee of National Liberation of September 6, 1944 on the Land Reform] (Dz.U. $1944 \mathrm{nr} 4$ poz. 17). 
Zarządzenie Ministrów Przemysłu i Skarbu z dnia 25 sierpnia 1945 r. w sprawie kredytów bankowych dla uruchomienia przemysłu na Ziemiach Odzyskanych [Ordinance of the Ministers of Industry and Treasury of August 25, 1945 on Bank Loans for Starting Industry in the Recovered Territories] (Dz.Urz. MZO 1946 nr 1 poz. 20).

Zarządzenie Ministra Aprowizacji i Handlu z dnia 6 października 1945 r. w sprawie dysponowania towarami poniemieckimi [Ordinance of the Minister of Supplies and Trade of October 6, 1945 on Disposing of Post-German Goods] (Dz.Urz. MZO 1946 nr 1 poz. 22).

Dekret z dnia 10 listopada 1945 r. o zmianie i ustalaniu imion i nazwisk [Decree of November 10, 1945 on Changing and Determining Names and Surnames] (Dz.U. $1945 \mathrm{nr} 56$ poz. 310).

Zarządzenie Ministra Ziem Odzyskanych z dnia 22 lutego 1946 r. w sprawie zakazu wywozu mienia ruchomego z Ziem Odzyskanych [Ordinance of the Minister of the Recovered Territories of February 22, 1946 Concerning Prohibiting the Removal of Movable Property from the Recovered Territories] (Dz.Urz. MZO nr 1 poz. 2).

Dekret z dnia 1 marca 1946 r. o Straży Obywatelskiej na obszarze Ziem Odzyskanych [Decree of March 1, 1946 on the Citizens' Guard in the Recovered Territories] (Dz.U. 1946 nr 10 poz. 71).

Dekret z dnia 8 marca 1946 r. o majątkach opuszczonych i poniemieckich [Decree on Abandoned and Formerly German Estates] (Dz.U. $1946 \mathrm{nr} 13$ poz. 87).

Zarządzenie Ministra Ziem Odzyskanych z dnia 24 marca 1946 r. w sprawie przeprowadzenia spisu poniemieckiego mienia ruchomego [Ordinance of the Minister of the Recovered Territories of March 24, 1946 on the Inventory of Post-German Movable Property] (Dz.Urz. MZO $1946 \mathrm{nr} 3$ poz. 25).

Zarządzenie Ministra Ziem Odzyskanych z dnia 6 kwietnia 1946 r. w sprawie trybu stwierdzania polskiej przynależności narodowej osób zamieszkałych na obszarze Ziem Odzyskanych [Ordinance of the Minister of the Recovered Territories of April 6, 1946 on the Procedure of Confirming Polish Nationality of Persons Residing in the Recovered Territories] (Dz.Urz. MZO $1946 \mathrm{nr} 4$ poz. 26).

Ustawa z dnia 28 kwietnia 1946 r. o obywatelstwie Państwa Polskiego osób narodowości polskiej zamieszkałych na obszarze Ziem Odzyskanych [Act of April 28, 1946 on the Citizenship of the Polish State of Polish Nationals Residing in the Recovered Territories] (Dz.U. $1946 \mathrm{nr} 15$ poz. 106).

Zarządzenie Ministrów: Administracji Publicznej i Ziem Odzyskanych z dnia 7 maja 1946 r. o przywróceniu i ustaleniu urzędowych nazw miejscowości [Ordinance of the Ministers of Public Administration and Recovered Territories of May 7, 1946 on the Restoration and Establishment of Official Names of Places] (M.P. $1946 \mathrm{nr} 44$ poz. 85).

Zarządzenie Ministra Ziem Odzyskanych z dnia 12 maja 1946 r. w sprawie premiowania osób, które przyczyniły się do wykrycia ukrytych remanentów poniemieckich lub do zatrzymania nielegalnie wywożonego mienia z terenu Ziem Odzyskanych [Ordinance of the Minister of the Recovered Territories of 12 May 1946 on Awarding Bonuses to Persons who Contributed to the Detection of Hidden post-German Inventories or to the Seizure of Property Illegally Removed from the Recovered Territories] (Dz.Urz. MZO $1946 \mathrm{nr} 4$ poz. 28).

Zarządzenie Ministra Administracji Publicznej z dnia 8 sierpnia 1946 r. o zmianie nazwy miejscowości "Parszywka" w gminie "Góry", powiecie pińczowskim, województwie kieleckim, na "Orkanów" [Ordinance of the Minister of Public Administration of August 8, 1946 on Changing the Name of the Village "Parszywka" in the Borough of "Góry", Pińczów County, Kielce Voivodeship, to “Orkanów”] (M.P. 1946 nr 83 poz. 154).

Rozporządzenie Ministrów: Administracji Publicznej i Ziem Odzyskanych z dnia 12 listopada 1946 r. o przywróceniu i ustaleniu urzędowych nazw miejscowości [Ordinance of the Ministers of Public Administration and Recovered Territories of November 12, 1946 on the Restoration and Establishment of Official Names of Places] (M.P. $1946 \mathrm{nr} 142$ poz. 262). 
Dekret z dnia 13 listopada 1946 r. o daninie narodowej na zagospodarowanie Ziem Odzyskanych [Decree of November 13, 1946 on the National Tribute for the Development of the Recovered Territories] (Dz.U. $1946 \mathrm{nr} 61$ poz. 341).

Okólnik Ministerstwa Ziem Odzyskanych nr 28, 16 marca 1946 r. [Circular of the Ministry of Recovered Territories No. 28, March 16, 1946] (Dz.Urz. MZO $1946 \mathrm{nr} 4$ poz. 38).

Rozporządzenie Ministra Administracji Publicznej z dnia 31 stycznia 1947 r. o zmianie nazwy osiedla "Boernerowo" na "Bemowo" [Ordinance of the Minister of Public Administration of January 31, 1947 on Changing the Name of the Estate "Boernerowo" to "Bemowo"] (M.P. $1947 \mathrm{nr} 76$ poz. 494).

Rozporządzenie Ministrów: Administracji Publicznej i Ziem Odzyskanych z dnia 15 marca 1947 r. o przywróceniu i ustaleniu urzędowych nazw miejscowości [Ordinance of the Ministers of Public Administration and Recovered Territories of March 15, 1947 on the Restoration and Establishment of Official Names of Places] (M.P. 1947 nr 37 poz. 297).

Konstytucja Polskiej Rzeczypospolitej Ludowej uchwalona przez Sejm Ustawodawczy w dniu 22 lipca 1952 r. [The Constitution of the People's Republic of Poland adopted by the Legislative Sejm on July 22, 1952] (Dz.U. $1952 \mathrm{nr} 33$ poz. 232).

Ustawa z dnia 13 czerwca 1967 r. o Ochotniczej Rezerwie Milicji Obywatelskiej [Act of June 13, 1967 on the Volunteer Reserve of Citizens' Militia] (Dz.U. 1967 nr 23 poz. 108). 